\title{
REVOLUSI MENTAL PADA LINGKUNGAN PENDIDIKAN DESA TERPENCIL
}

\author{
Dodo Sutardi \\ Dihamri \\ Nurmintan Silaban \\ Fakultas Keguruan dan Ilmu Pendidikan, Universitas Prof. Dr.Hazairin, SH. \\ Jalan A Yani No 1 Bengkulu. \\ email: masdo.061960@gmail.com
}

\begin{abstract}
The research purpose is create and examine the effectiveness of mental revolution model based on local wisdom at remote area. This model used to increase of teachers understanding and application mental revolution at remote primary school Seluma, Bengkulu. This research used qualitative descriptive and experiment with One Group Pretest-Posttest Designe. The research results showed that (1) the mental revolution at remote education environment is a model of coaching the values of mental revolution based on the local wisdom through socialization, taglinne spread, and commemoration of national day,(2) this model is effective to increasing teachers understanding and application mental revolution values.
\end{abstract}

Keyword: mental revolution, local wisdom, remote elementary school

\begin{abstract}
Abstrak: Penelitian ini bertujuan menghasilkan model revolusi mental berbasis kearifan lokal desa terpencil dan menguji keefektifannya dalam meningkatkan pemahaman serta penerapan nilai-nilai revolusi mental para guru di SD terpencil. Penelitian dilakukan di SD terpencil Kabupaten Seluma, Provinsi Bengkulu. Penelitian ini menggunakan pendekatan deskriptif kualitatif dan eksperimen model One Group Pretest-Posttest Designe. Hasil penelitian menunjukkan (1) revolusi mental pada lingkungan pendidikan desa terpencil adalah model pembinaan nilai revolusi mental berbasis kearifan lokal melalui sosialisasi, pemasangan tagline, dan upacara hari besar nasional; (2) model revolusi mental berbasis kearifan lokal efektif dalam meningkatkan pemahaman dan penerapan nilai-nilai revolusi mental para guru di SD terpencil.
\end{abstract}

Kata kunci: revolusi mental, kearifan lokal, SD terpencil

Revolusi mental pada lingkungan pendidikan di desa terpencil dibangun atas dasar gagasan program Nawacita. Pada butir ketiga disebutkan bahwa "membangun Indonesia dari pinggiran dengan memperkuat daerah-daerah dan desa dalam kerangka negara kesatuan". Sedangkan Mendikbud (2016) menjelaskan bahwa revolusi mental harus benar-benar dikondisikan di sekolah sesuai dengan Nawacita yakni "melakukan revolusi karakter bangsa melalui kebijakan penataan kembali kurikulum pendidikan nasional". Praktek revolusi mental dalam kehidupan sehari - hari adalah menjadi ma- nusia yang berintegritas, memiliki etos kerja, dan semangat gotong royong. Oleh karen itu nilai-nilai esensial yang dikembangkan sebagai pengungkit revolusi mental adalah (1) integritas yang terdiri atas jujur, dipercaya, berkarakter dan tanggug jawab; (2) etos kerja yang terdiri atas kerja keras, optimis, inovatif dan produktif; dan (3) gotong royong yang terdiri atas kerjasama, solidaritas, komunal, berorientasi pada kemaslahatan (Jansen, 2014:72).

Bagi guru nilai-nilai tersebut adalah indikatorindikator kompetensi pribadi dan kompetensi sosial yang seharusnya sudah teraplikasikan dalam 
kehidupan sehari-hari khususnya dalam menjalankan tugasnya sebagai guru yang profesional. Hal ini sesuai dengan pendapat Wardani (2010) bahwa guru berperan penting dalam pembentukan karakter di sekolah. Salah satu alasan untuk hal tersebut antara lain hasil riset Bank Dunia tahun 2009-2011, bahwa upaya profesionalisme guru dengan sertifikasi tidak berimplikasi pada peningkatan kualitas guru dan kualitas hasil belajar siswa. Peningkatan tersebut tidak berbanding lurus dengan peningkatan profesionalisme atau kinerja guru sehingga hanya memperbaiki ekonomi guru dan meningkatkan minat menjadi guru, bahkan ada indikasi menunjukan dampak buruk berupa gejala mental materialistis yang perlu diantisipasi (Murwati, 2013). Temuan peneliti tentang upaya peningkatan kinerja guru SD terpencil di Bengkulu oleh Dodo (2016) menunjukkan bahwa terbengkalainya pembelajaran di SD terpencil bukan saja karena kekurangan guru, namun diakibatkan karena banyak guru PNS yang mendapat tunjangan pendidik dan tunjangan daerah terpencil mangkir dari tugasnya. Menurut data SMERU Research Institute, sebanyak 31,5\% guru sekolah dasar di daerah terpencil yang mangkir adalah PNS penerima tunjangan khusus. Menurut data Education Sector Analytical and Capacity Development Partner tahun 2014, bahwa tingkat kemangkiran guru sekolah dasar di daerah terpencil mencapai $20 \%$ lebih banyak dibandingkan dengan tingkat kemangkiran nasional yang hanya $9,4 \%$. Hal ini berdampak pada kemampuan membaca, menulis dan berhitung siswa yakni sebanyak $60 \%$ siswa kelas 1 sekolah dasar di daerah terpencil masih buta huruf (ACDP Indonesia, 2015). Persoalannya bukan pada masalah kompetensi pedagogik dan profesional guru, tetapi persoalan aplikasi indikator-indikator kompetensi sosial dan kompetensi pribadi yang notabene searah dengan nilai-nilai revolusi mental. Maka membina kompetensi pribadi dan kompetensi sosial guru juga harus diiringi dengan membina nilai-nilai revolisi mental.

Langkah-langkah proses internalisasi nilainilai revolusi mental dalam jangka pendek, dilakukan melalui berbagai kegiatan seperti (1) mensosialisasikan nilai-nilai revolusi mental melalui pertemuan-pertemuan; (2) membuat tagline revolusi mental di berbagai ruang berupa suatu ungkapan pendek bersisi pesan yang padat dan mudah diingat; dan (3) membuat atau memberikan role model untuk dapat dicontoh dan menjadi tauladan bagi masyarakat (Arief, 2015). Pada lingkungan pendidikan desa terpencil gerakan itu harus melibatkan warga sekolah sebagai raw input dan instrument input, dan masyarakat sebagai environmental input dengan nilai-nilai kearifan lokal yang telah tumbuh dan berkembang dalam kehidupan sehari-sehari dengan segala keterbatasan dengan keunikannya, konsisten dan komitmen terhadap adat kebiasaan yang telah tumbuh kembang sebagai dasar dalam menjalankan kehidupannya termasuk dalam mendidik anak. Adat kebiasaan itu berisikan nilai-nilai yang tumbuh kembang menjadi sebuah kearifan lokal (Dihamri, 2010).

Salah satu kekayaan Provinsi Bengkulu adalah keragaman suku, dan adat istiadat. Ada delapan suku asli dan beberapa suku pendatang. Kedelapan suku asli adalah suku Lembah, Serawai, Mukomuko, Pekal, Kaur, Basemah dan Suku Enggano. Dari ke-8 suku tersebut yang mendasari kehidupan dan menjadi kearifan lokal desa-desa terpencil adalah suku Serawai dan Enggano. Berikut nilai-nilai kearifan lokal Suku Serawai yang diidentifikasi dari siklus hidup, hubungan dengan sesama, keberagamaan, pengembangan diri, peningkatan ekonomi (Dihamri, 2016), lihat tabel 1.

Sedangkan nilai-nilai revolusi mental pada kearifan lokal Suku Enggano mengungkap lebih dalam tentang adat istiadat yang tergambar pada upacara adat, mata pencaharian, kehidupan bermasyarakat, sistem kekerabatan, bahasa, dan seni Ekorusyono (2013), lihat tabel 2.

Berdasarkan hal tersebut, fokus analisis nilainilai yang akan dijadikan dasar dalam menyusun model revolusi mental pada lingkungan pendidikan berbasis kearifan lokal desa terpencil akan bersumber pada kedua suku tersebut. Hal ini didasarkan pada pendidikan dan kebudayaan yang harus dipandang sebagai proses kreatif yang tidak dapat dipisahkan, ibarat dua sisi dari keping uang yang sama. Bung Hatta menyatakan bahwa yang diajarkan dalam proses pendidikan adalah kebudyaan, sedangkan pendidikan itu sendiri adalah proses pembudayaan (Latif, 2014:28). Oleh karena itu jika gerakan revolousi mental dipandang sebagai proses pendidikan, maka proses itu harus bersumber dan berupaya mengembangkan nilai-nilai budaya setempat. 
Tabel 1. Kearifal Lokal Suku Serawai

\begin{tabular}{|llll|}
\hline No. & \multicolumn{1}{c}{ Kearifan Lokal } & \multicolumn{1}{c}{ Penjelasan } & Nilai Revolusi Mental \\
\hline 1. & Berayak & Laki-laki berkelompok/berteman dua tiga orang & Gotong royong: \\
& Kunjungan pemuda & atau lebih berkunjung ke rumah seorang gadis yang & • Solidaritas \\
kerumah pemudi di- & berlainan desa, tujuannya silaturahmi dan perkenalan. & • Komunal \\
jam $20.00-22.00$ & kertemuan dilakukan di ruang tamu membincangkan & \\
& kegiatan sehari-hari. Apabila ada kepentingan yang & \\
& sifatnya serius misalnya ingin menyatakan cinta, harus & \\
& disampaikan secara tertulis.
\end{tabular}

2. Betembang Melantunk- Isi sair mengisahkan kegiatan sehari-hari atau menan syair atau pantun diiringi gitar tunggal

3. Andung

Kunjungan dalam acara pernikahan

4. Padu padan kulau, acara penyambutan keluarga mempelai laki-laki sebelum upacara ijab kabul/pemberkatan

5. Andai-andai, melantunkan kisah seseorang yang termashur tanpa music

6. Nueni Memulai mengerjakan sawah/kebun

7. Nueuni Acara syukuran panen hasil sawah/kebun

8. Belaeam Pesan untuk me-ngembangkan diri

9. Neman

10. Ibau Berupaya lebih baik

11. Hemat

Ajaran untuk hemat yang didikan orang tua pada anaknya gisahkan percintaan dikalangan muda mudi

Dilaksanakan dengan acara bimbang adat (acara persepsi pernikahan dengan tarian adat (tari andun), dilakukan selama 3 hari sbagai anjang pertemuan muda mudi, keluarga dan kerabat dua mempelai

Izin keluarga mempelai wanita kepada ketua adat sebagai pimpinan kampung untuk melakukan upacara pernikan.

Dilaksanakan apabila ada kematian atau acara adat lainnya, oleh orang tua yang memiliki kemampuan

Sebelum bercocok tanam warga secara bersama-sama membersihkan lahan

Dilaksanakann pada hari pertama pamen padi. Pertama panen mengambil tujuh batang padi

Disampaikan para tokoh adat dalam berbagai pertemuan dengan tujuan untuk mencapai keberhasilan akan usaha yang dilakukan

Sebutan bagi seorang pemuda atau pemudi yang bekerja keras atau lebih rajin dari biasanya dalam usaha panen sawah/kebun

Berusaha menghasilkan hasil pertanian yang lebih dari hasil masyarakat pada umumnya

Setelah panen, masyarakat Serawai menyimpan panennya untuk sampai musim panen berikutnya, dan menjual sebagian untuk keperluan kehidupan lainnya.
Integritas;

- Berkarakter

Gotong royong:

- Solidaritas

- Komunal

- Beorientasi pada kemaslahatan bersama

Integritas:

- Menghargai pemimpin/tokoh

- Tanggung jawab

- Berkarakter

Gotong royong

- Solidaritas

- Komunal

- Beorientasi pada kemaslahatan bersama

Integritas; Bersukur
Etos kerja:

- Kerja keras

- Inovatif

- Produktif 
Tabel 2. Kearfifan Lokal Suku Enggano

\begin{tabular}{|c|c|c|c|}
\hline No. & Kearifan Lokal & Penjelasan & Nilai Revolusi Mental \\
\hline \multirow[t]{4}{*}{1.} & \multirow{4}{*}{$\begin{array}{l}\text { Yakarea kaudadaPesta } \\
\text { kebesaran adat seperti } \\
\text { peresmian rumah adat } \\
\text { pengukuhan nama } \\
\text { perkampungan, pen- } \\
\text { gukuhan kepala suku, } \\
\text { perkawinan bujang } \\
\text { gadis }\end{array}$} & $\begin{array}{l}\text { Pesta kebesaran adat melibatkan semua suku, } \\
\text { Diwajibkan pada warga suku menyumbang hasil } \\
\text { pertaniannya, dan perlengkapan seperti kampak atau } \\
\text { parang bagi laki-laki dan bagi perempuan perleng- } \\
\text { kapan masak, ditambah dengan uang kontan recehan } \\
\text { seribuan sepuluh lembar }\end{array}$ & $\begin{array}{l}\text { Gotong royong: } \\
\text { - Solidaritas } \\
\text { - Komunal } \\
\text { - Beorientasi pada ke- } \\
\text { maslahatan bersama }\end{array}$ \\
\hline & & $\begin{array}{l}\text { Beberapa persyaratan yang harus dipenuhi, jika di- } \\
\text { langgar maka akan dikenakan sangsi adat }\end{array}$ & menanamankan disiplin \\
\hline & & $\begin{array}{l}\text { Jika masih ada sengketa diantara suku (karena ada } \\
\text { aduan, atau atas kesadaran yang bersangkutan untuk } \\
\text { melapor pada ketua suku/ketua adat), maka upacara } \\
\text { sepenting dan seurgen apapun, tidak dapat dilang- } \\
\text { sungkan sebelum sengketa itu dapat diselesaikan. }\end{array}$ & $\begin{array}{l}\text { Integritas: } \\
\text { - Kejujuran } \\
\text { - Komitmen } \\
\text { - Tanggung jawab }\end{array}$ \\
\hline & & $\begin{array}{l}\text { Memeriahkan upacara pendahuluan 'Padoowa'a } \\
\text { ukakabakke" yakni upacara mendoakan keluarga } \\
\text { yang sudah almarhum. Dilaksanakan malam hari } \\
\text { dihadiri (wajib) oleh suku sahabat. Pada siang } \\
\text { harinya mengikuti upacara yabo'i yuuwa'a kakabake } \\
\text { yaitu upaca pengaturan pembagian pembagian hasil } \\
\text { kekayaan adat. }\end{array}$ & $\begin{array}{l}\text { Gotong royong: } \\
\text { - Solidaritas } \\
\text { - Komunal } \\
\text { - Beorientasi pada ke- } \\
\text { maslahatan bersama }\end{array}$ \\
\hline \multirow[t]{4}{*}{2.} & \multirow[t]{4}{*}{$\begin{array}{l}\text { Hukum adat Pelestar- } \\
\text { ian lingkungan }\end{array}$} & $\begin{array}{l}\text { Aturan pembukaan lahan bagi penduduk asli harus } \\
\text { melalui musyawarah anggota suku untuk menentu- } \\
\text { kan lokasi dan ukuran. Bagi investor atau program } \\
\text { pemerintah harus melalui musyawarah suku.Bagi } \\
\text { yang melanggar dikenakan sangsi menanam kembali } \\
\text { hutan yang telah ditebangnya. }\end{array}$ & $\begin{array}{l}\text { Gotong royong: } \\
\text { - Solidaritas } \\
\text { - Komunal } \\
\text { - Beorientasi pada ke- } \\
\text { maslahatan bersama }\end{array}$ \\
\hline & & $\begin{array}{l}\text { Pengambilan hasil hutan oleh penduduk tidak boleh } \\
\text { diperjual belikan ke luar pulau Enggano. Bagi yang } \\
\text { melanggar dikenai denda uang RP. } 25.000 .000,00 \\
\text { dan menghijaukan kembali hutan yang telah dite- } \\
\text { bang. }\end{array}$ & $\begin{array}{l}\text { Integritas: } \\
\text { - Tanggung jawab } \\
\text { - Disiplin } \\
\text { - Komitmen }\end{array}$ \\
\hline & & $\begin{array}{l}\text { Penangkapan satwa, dibolehkan untuk mengambil } \\
\text { anaknya secara berkala pada tahun ganjil, dan dila- } \\
\text { rang untuk mengambilnya pada bulan genap. }\end{array}$ & \\
\hline & & $\begin{array}{l}\text { Bagi pendatang tidak dibolehkan menangkap satwa } \\
\text { langsung ke hutan kecuali sudah menjadi penduduk } \\
\text { tetap. Bagi yang melanggar harus melepaskan kem- } \\
\text { bali hasil tangkapannya dengan disaksikan kepala } \\
\text { suku }\end{array}$ & \\
\hline 3. & $\begin{array}{l}\text { Yapuruhie } \\
\text { Masa pantang pada } \\
\text { saat ada warga yang } \\
\text { meninggal dunia (ti- } \\
\text { dak berlaku jika yang } \\
\text { meninggal bayi }<10 \\
\text { bulan) }\end{array}$ & $\begin{array}{l}\text { Masyarakat dilarang melakukan kegiatan rame-rame } \\
\text { selam } 1 \text { sampai dengan } 2 \text { minggu seperti kegiatan } \\
\text { pernikahan, membunyikan musik apalagi melakukan } \\
\text { perbuatan penyelewengan seperti berzina,. Apabila } \\
\text { ada yang melanggar akan dikenakan sangsi sesuai } \\
\text { dengan ketentuan masing-masing sukunya }\end{array}$ & $\begin{array}{l}\text { Solidaritas, empati, } \\
\text { simpati } \\
\text { Kejujuran } \\
\text { Tanggung Jawab }\end{array}$ \\
\hline
\end{tabular}

Sumber: Katalog Koleksi Musium Bengkulu, (2006) 


\section{METODE}

Penelitian ini dirancang untuk mengembangkan model revolusi mental pada lingkungan pendidikan desa terpencil di Kabupaten Seluma, Provinsi Bengkulu yang berbasis kearifan lokal. Penelitian ini menggunakan model Research and Development (Sugiyono 2011:298). Data awal yang digunakan untuk pengembangan model adalah nilai-nilai kearifan lokal desa terpencil, kompetensi sosial, dan kompetensi pribadi guru PNS SD terpencil sebagai dasar pengembangan model. Data dianalisis menggunakan model Miles and Huberman (Sugiyono, 2011:247). Model yang telah dikembangkan diuji secara teoritik maupun empirik yang dilakukan melalui (a) konstruk teoritik, (b) validasi pakar dalam bentuk fokus group discussion (FGD), dan (c) uji coba.

Untuk melakukan uji coba, sampel diambil secara purfosif, yakni guru SD terpencil dengan status PNS yang terdiri atas guru yang telah menerima tunjangan pendidik dan tunjangan daerah tepencil berjumlah 38 orang, dan guru yang bertugas di 8 SD terpencil Kabupaten Seluma. Untuk uji coba digunakan model eksperimen One Group Pretest-
Posttest Designe (Saxe \& Fine, 1989:103; Sugiyono, 2011 :79). Pretest dilakukan sebelum pelaksanaan gerakan revolusi mental pada 8 SD terpencil dengan kegiatan sosialisasi, penyebaran tagline, dan penyelenggaraan upacara peringatan hari ulang tahun Republik Indonesia ke 72. Kemudian setelah kegiatan selama satu bulan akan diadakan posttest. Data hasil uji coba dianalisis menggunakan uji-t untuk mengetahui peningkatan pemahaman dan penerapan nilai nilai revolusi mental oleh guru-guru PNS di SD terpencil Kabupaten Seluma.

\section{HASIL}

\section{Model Revolsi Mental Berbasis Kearifan Lokal Desa Terpencil}

Merujuk pada model pembelajaran sebagai input, poses, dan output maka model revolusi mental pada lingkungan pendidikan berbasis kearifan lokal desa terpencil didesain pada gambar 1.

Ada tiga jenis input, yaitu raw input, instrumental input, dan environmental input. Raw input dalam model revolusi mental yang dimaksud teriri dari ; 1) nawa cita ke 3, yakni; membangun Indo-

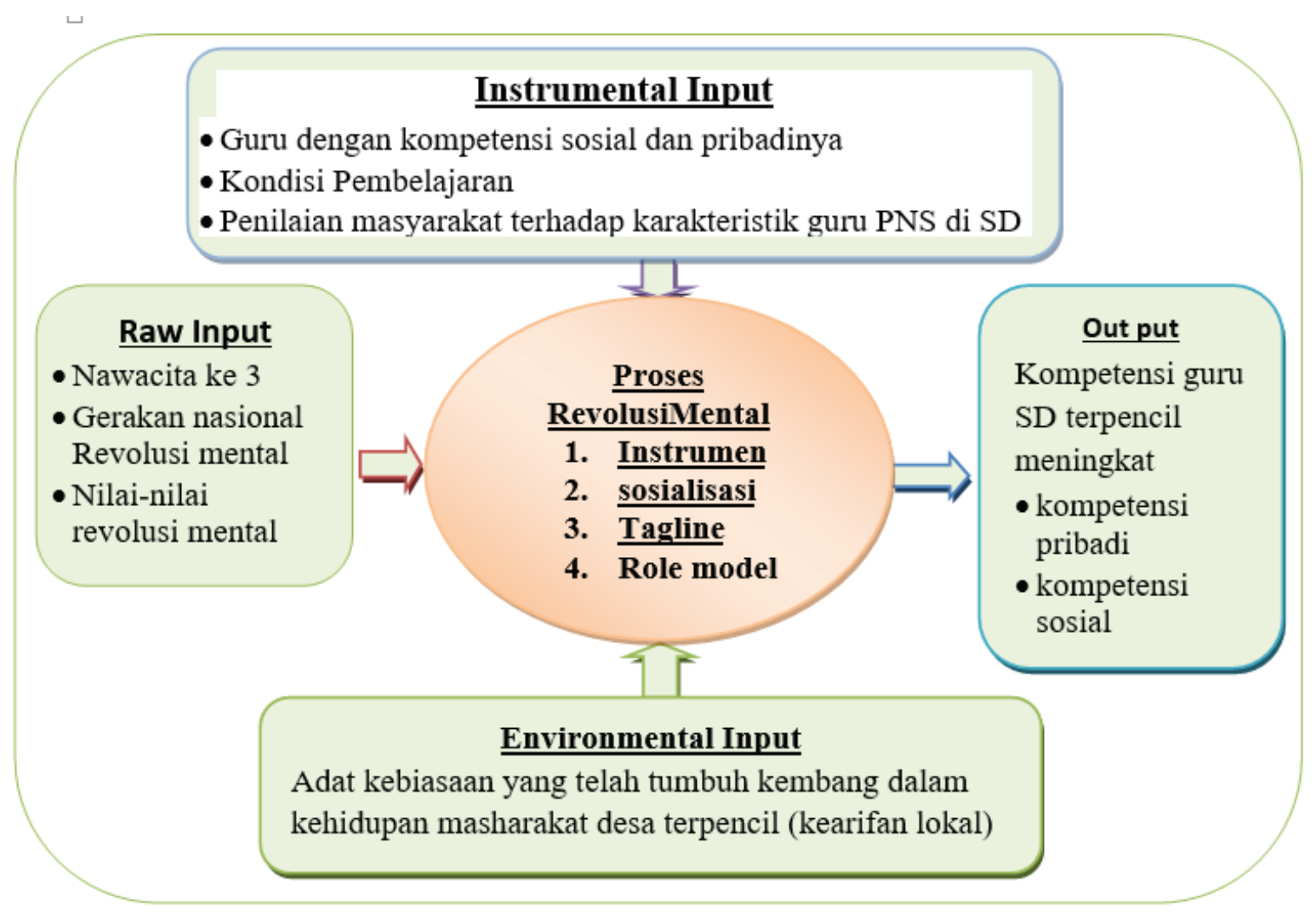

Gambar 1. Model Revoliusi Mental Pada Lingkungan Pendidikan Berbasis Kearifan Lokal 
nesia dari pinggiran dengan memperkuat daerahdaerah dan desa dalam kerangka negara kesatuan, 2) gerakan revolusi mental, 3) nilai-nilai revolusi mental. Instrumen inputnya terdiri atas guru dengan kompetensi pribadi dan kempetensi sosialnya, proses pembelajaran, dan persepsi masyarakat terhadap pribadi dan kompetensi sosial guru. Untuk proses revolusi mental dijelaskan dalam Panduan Pencanangan dan Sosialisasi Gerakan Nasional Revolusi Mental, bahwa langkah-langkah proses internalisasi nilai-nilai revolusi mental dalam jangka pendek dilakukan melalui berbagai kegiatan; 1) mensosialisasikan nilai-nilai revolusi mental melalui pertemuan-pertemuan, 2) membuat tagline revolusi mental di berbagai ruang berupa suatu ungkapan pendek bersisi pesan yang padat dan mudah diingat, 3) membuat atau memberikan role model, untuk dapat dicontoh dan menjadi tauladan bagi masyarakat. Instrumen nilai-nilai revolusi mental pada lingku-ngan pendidikan desa terpencil berisikan 50 butir pernyataan.

Pernyataan dengan sebanyak lima puluh butir disebarkan dalam bentuk angket sebelum dan sesudah dilaksanakannya gerakan revolusi mental untuk memperoleh skor yang menggambarkan tingkat pemahaman dan penerapan nilai-nilai revolusi mental setiap guru. Berikut tabel kategori tingkat pemahaman dan penerapan nilai revolusi mental.

Tabel 3. Kategori Tingkat Pemahaman dan Penerapan Nilai-nilai Revolusi Mental

\begin{tabular}{ccc}
\hline No. & Interval Skor & $\begin{array}{c}\text { Kategori Tingkat Pema- } \\
\text { haman dan Penerapan }\end{array}$ \\
\hline 1. & $210>$ & Sangat Tinggi \\
2. & $170-209$ & Tinggi \\
3. & $130-169$ & Sedang \\
4. & $90-129$ & Rendah \\
5. & $50-89$ & Sangat Rendah \\
\hline
\end{tabular}

\section{Hasil Sosialisasi Nilai-Nilai Revolusi Mental melalui Model}

Berbeda dengan kegiatan sosialisasi pada umumnya, sosialisasi nilai-nilai revolusi mental pada lingkungan pendidikan desa terpencil dilakukan secara tidak formal pada saat masyarakat berkumpul, misalnya menjelang pesta perkawinan. Kebiasaan mereka berkumpul kurang lebih selama 9 malam, melakukan berbagai acara dengan menampilkan tarian-tarian adat atau sekedar main gapleh dan se- bagainya. Pada saat ini tanpa direncanakan terjadi dialog atau bincang-bincang tentang nilai-nilai kehidupan bermasyarakat. Keikutsertaan guru-guru pada kegiatan seperti itu sangat dibutuhkan sebagai role model penerapan nilai-nilai kearifan lokal, sekaligus memantapkan kompetensi sosial dan kompetensi pribadi guru-guru dalam kehidupan bermasyarakat.

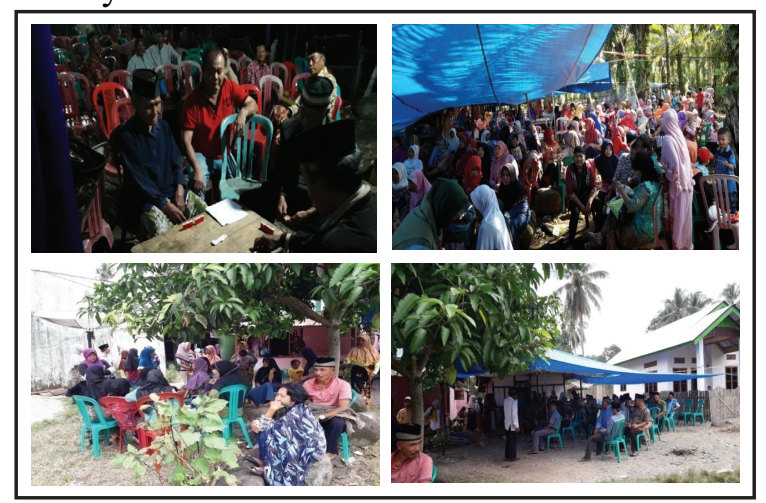

Gambar 2. Contoh Sosialisasi dengan masyarakat

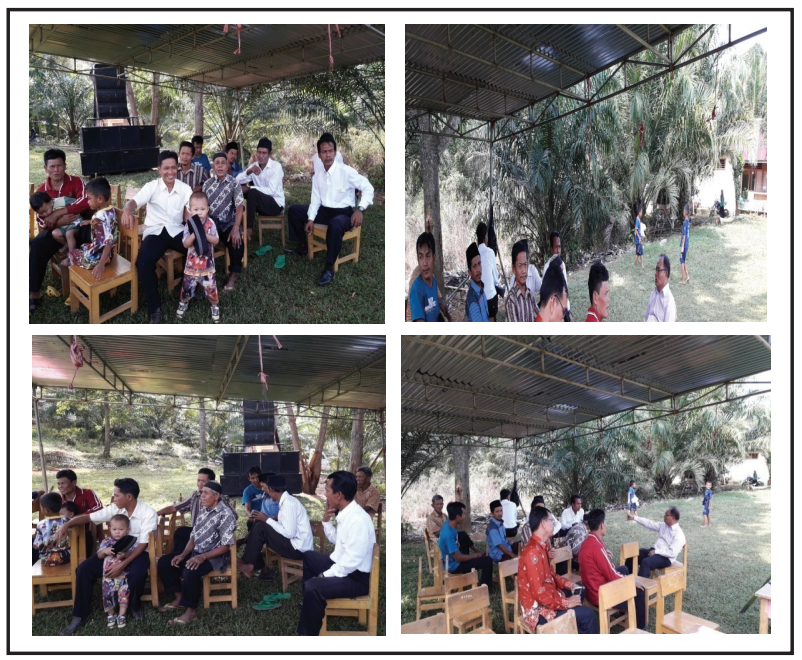

Gambar 3. Contoh Sosialisasi dengan Guru

Sedangkan untuk pemasangan tagline untuk lingkungan pendidikan desa terpencil dirancang dan dibuat oleh warga sekolah dan masyarakat yang merepresentasikan harapan dirinya. Membuat tagline oleh warga sekolah dan masyarakat diawali dengan diskusi nilai-nilai positif yang inspiratif untuk di susun dalam bentuk frasa yang unik, lucu, menginspirasi, atau bahkan sindiran yang berupa sarkasme, ditulis dalam kertas karton dihiasi dengan gambar-gambar dan bahasa sesuai selera masing-masing. Hasilnya dilombakan pada upacara memperingati HUT RI, ditempelkan pada dindingdinding kelas yang strategis untuk dibaca. 


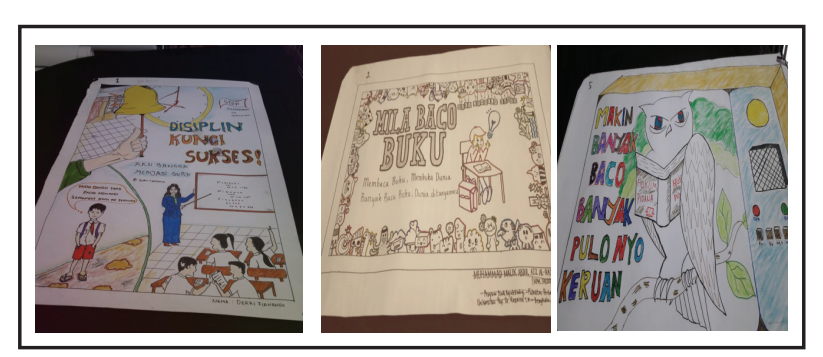

Gambar 4. Contoh Tagline karya guru, masyarakat dan siswa, dalam Bahasa Daerah

Upacara memperingati hari ulang tahun RI di lingkungan SD terpencil menjadi bagian dari langkah-langkah gerakan revolusi mental. Upacara dilaksanakan dengan melibatkan masyarakat sebagai peserta maupun sebagai petugas upacara. Kegiatan dilanjutkan dengan berbagai lomba dan hiburan rakyat yang mengandung nilai-nilai integritas, etos kerja dan gotong royong.

Output dari gerakan revolusi mental pada lingkungan pendidikan desa terpencil, adalah meningkatnya kompetensi pribadi dan kompetensi sosial, sebagai aplikasi dari pemahaman dan penerapan nili-nilai revolusi mentalm oleh guru. Oleh karena itu tingkat kompetensi pribadi dan sosial guru dapat diukur dari sejauh mana guru tersebut memahami dan mengaplikasikan nilai-niai revolusi mental: 1) integritas; jujur, dipercaya, berkarakter dan tanggug jawab, 2) etos kerja; kerja keras, optimis, inovatif dan produktif, dan 3) gotong royong; kerjasama, solidaritas, komunal, beorientasi pada kemaslahatan.

\section{Hasil Uji Coba Model}

Model yang dimaksud adalah model revolusi mental pada lingkungan pendidikan desa terpencil. Untuk melakukan uji coba model, disebarkan instrumen untuk memperoleh gambaran pemahaman dan penerapan nilai-nilai revolusi mental oleh guru PNS di desa terpencil sebelum diterapkan model (tes awal). Setelah diterapkan model, dalam waktu satu setengah bulan, dilakukan tes akhir, maka diperoleh data skor hasil tes awal dan tes akhir.

Terhadap kedua kelompok skor, dilakukan uji perbedaan, dengan terlebih dahulu menghitung skor-skor yang akan digunakan dalam rumus uji beda, yakni menguji perbedaan rata-rata skor pemahaman dan penerapan nilai-nilai revolusi mental oleh guru PNS yang bertugas di SD terpencil Ka- bupaten Seluma Provinsi Bengkulu sebelum dan sesudah diterapkan model Revolusi mental berbasis kearifan lokal desa terpencil. Rata-rata skor sebelum diterapkan model sebesar 135,47 dengan varians 80,94 . dan sesudah diterapkan model sadalah 193,47 dengan varians 64.37. Hasil perhitungan diperoleh $\mathrm{t}_{\mathrm{h}}=15,17$.

\section{PEMBAHASAN}

Pada ketiga jenis input model revolusi mental kegiatan-kegiatan yang akan dilakukan dalam merealisasikan gerakan revolusi mental harus disesuaikan dengan kondisi dan kebiasaan belajar siswa karena itu siswa harus menjadi bagian dari instrumen input. Hasil pengataman mahasiswa yang melaksanakan Kuliah Kerja Nyata (KKN) di desa terpencil tempat penelitian dilaksanakan memberikan gambaran bahwa pembelajaran di SD terpencil Kecamatan Lubuk Sandi kurang kondusif karena kegiatan belajar tidak terjadwal meskipun secara formal telah dipasang jadwal pembelajaran pada setiap kelas. Ketiga jenis input itu harus menjadi dasar dalam menanamkan, mengembang-kan dan merealisasikan nilai-nilai integritas, etos kerja dan gotong royong sebagai inti revolusi mental, dengan asumsi bahwa gerakan revolusi mental bukan pekerjaan sehari dua hari, tetapi usaha nasional jangka panjang yang terus menerus untuk menentukan masa depan bangsa, kegiatannya harus dilakukan secara terarah dan sistematitis pada semua lini kehidupan, termasuk lingkungan pendidikan (Ignas, 2014:59). Pemerintah harus memiliki program yang jelas dalam revolusi mental. Selain itu, partisipasi masyarakat dari segala lapisan juga diperlukan karena inisiatif negara saja dalam menafsirkan dan menjalankan revolusi mental tidaklah cukup.

Pada proses revolusi mental lingkungan pendidikan desa terpencil, proses itu diawali dengan menilai pemahaman dan aplikasi nilai-nilai revolusi mental sebelum dan sesudah dilaksanakan sosialisaasi, masang tagline, dan upacara memperingati HUT RI sebagai role model. Pada pemasangan tagline, tagline untuk lingkungan pendidikan desa terpencil dirancang dan dibuat oleh warga sekolah dan masyarakat yang merepresentasikan harapan dirinya. Fungsi tagline ini untuk meningkatkan awareness. Untuk itu, agar dapat memberikan efek maksimal, tagline haruslah dibuat dengan tepat dan digunakan pada tempatnya, menggunakan 
bahasa yang capat dipahaminya (bahasa daerah misalnya). Tagline yang baik adalah tagline yang fleksibel dan dapat merepresentasikan identitas, (Dwi, 2015). Membuat tagline oleh warga sekolah dan masyarakat diawali dengan diskusi nilai-nilai positif yang inspiratif untuk di susun dalam bentuk frasa yang unik, lucu, menginspirasi, atau bahkan sindiran yang berupa sarkasme, ditulis dalam kertas karton dihiasi dengan gambar-gambar dan bahasa sesuai selera masing-masing. Hasilnya dilombakan pada upacara memperingati HUT RI, ditempelkan pada dinding-dinding kelas yang strategis untuk dibaca.

Pada upacara peringatan hari besar nasional juga ditingkatkan pemahaman dan penerapan nilai-nilai revolusi mental oleh warga sekolah dan masyarakat. Menpora (2017) menyampaikan, bahwa upacara peringatan HUT RI adalah role model revolusi mental dan bendera Merah Putih selamanya harus di kawal serta di junjung tinggi. Oleh sebab itu, apel kebangsaan sangat penting bagi seluruh warga masyarakat (Risalah, 2017). Upacara peringatan hari besar nasional ini menjadi perioritas dalam gerakan revolusi mental di SD terpencil, karena hasil identifikasi menunjukkan bahwa di SD terpencil jarang dilaksanakan upacara peringatan hari nasional bahkan upacara pada hari senin tidak dilaksanakan. Upacara dilaksanakan dengan melibatkan masyarakat sebagai peserta maupun sebagai petugas upacara.

Guru memiliki tanggung jawab atas terlaksananya nilai-nilai revolusi mental pada lingkungan pendidikan. Oleh karena itu, guru harus membangun kepercayaan akan dirinya pada peserta didik. Terdapat beberapa hal yang perlu diperhatikan oleh guru untuk menguatkan proses pembentukan kepribadian peserta didik, diantaranya adalah mengaplikasikan nilai-nilai revolusi mental sebagai perwujudan kompetensi pribadi dan kompetensi sosial. Kegiatan-kegiatan yang akan dilakukan dalam merealisasikan gerakan revolusi mental harus disesuaikan dengan kondisi dan kebiasaan belajar siswa, karena itu siswa harus menjadi bagian dari instrumen input.

Hasil pengataman mahasiswa yang melaksanakan Kuliah Kerja Nyata (KKN), di desa terpencil tempat penelitian dilaksanakan, memberikan gambaran, bahwa pembelajaran di SD terpencil kecamatan Lubuk Sandi kurang kondusif, karena kegiatan belajar tidak terjadwal meskipun secara formal telah dipasang jadwal pembelajaran pada setiap ke- las. Banyak siswa kelas 1 yang belum pandai membaca, bahkan ada beberapa siswa kelas 4 juga belum pandai membaca. Banyaknya guru SD terpencil yang mangkir dari tugasnya, tidak saja menghambat proses dan pecapain tujuan pembelajaran, tetapi juga telah mengurangi kepercayaan masyarakat terhadap guru. Hal ini sesuai dengan hasil penelitian Ana (2015) bahwa kinerja guru berpengaruh dalam merepresentasikan pencapai hasil belajar siswa. Adanya permasalahan tersebut menyebabkan guru kehilangan kepercayaan sebagai sumber penguat nilai-nilai positif yang sudah tumbuh kembang dalam kehidupan bermasyarakat sebagaimana dijelaskan oleh Suprastowo (2013) bahwa tingkat ketidakhadiran guru sekolah dasar dan dampaknya terhadap siswa. Untuk itu masyarakat sebagai instrumen input menjadi bagian dari komponen yang diikutsertakan dalam gerakan revolusi mental pada lingkungan pendidikan.

Adat kebiasaan yang telah tumbuh kembang dalam kehidupan masyarakat desa terpencil sebagai kearifan lokal menjadi bagian yang telah mewarnai kondisi dan keberadan pendidikan di desa terpencil. Hal ini sesuai dengan pendapat Arianto, \& Agung (2013) bahwa lingkungan dan budaya berpengaruh terhadap kinerja guru. Maka hal itu harus menjadi bagian dari masukan (environmental input) dalam merancang model revolusi mental pada lingkungan pendidikan desa terpencil. Anik (2017) dalam pengembangan pembelajaran berbasis nilai-nilai budaya Yogyakarta di sekolah dasar menyimpulkan bahwa model pembelajaran berbasis budaya ini digunakan untuk menanamkan nilai-nilai budaya di sekolah dasar terutama yang berkaitan dengan format rencana pelaksanaan pembelajaran (RPP). Selain itu, Akamal (2017) juga menjelaskan pentingnya budaya lokal dan moral lokal untuk melengkapi Pengetahuan Konten Pedagogi Teknologi $(\mathrm{TPCK}+)$ dalam tantangan keterampilan abad 21. Guru sebagai role model dalam merealisasikan nilai-nilai integritas dan etos kerja akan memotivasi warga sekolah lainnya untuk sama-sama berupaya meningkatkan integritas dan etos kerja serta gotong royong dalam membangun pendidikan di desa terpencil.

Pada hasil uji coba, uji hipotesis, jika $t_{h}>$ $\mathrm{t}_{\mathrm{t}}$ maka Ho di tolak. Dengan $\alpha \quad 0,05$ dk $\mathrm{n}-1=$ 37, maka diperoleh $\mathrm{t}_{\mathrm{t}}=2,750$. Diketahui $\mathrm{t}_{\mathrm{h}}=15,17$. Maka $t_{h}>t_{t}$, jadi $H_{o}$ ditolak (Raja, 2017). Dengan demikian penerapan model revolisi mental pada 
lingkunghan pendidikan berbasis kearifan lokal dapat meningkatkan pemahaman dan penerapan nilainilai revolusi mental oleh guru PNS desa terpencil. Nilai-nilai revolusi mental yang terdiri atas integritas, etos kerja dan gotong royong searah dengan indikator kompetensi pribadi dan kompetensi sosial. Dalam penjelasan PP No 19 Tahun 2005 tentang Standar Nasional Pendidikan disebutkan bahwa kompetensi kepribadian guru yaitu kemampuan kepribadian guru yang terdiri atas (1) kemantapan, (2) stabil, (3) dewasa, (4) arif dan bijaksana, (5) berwibawa, (6) berakhlak mulia, (7) menjadi teladan bagi peserta didik dan masyarakat, (8) mengevaluasi kinerja sendiri, dan (9) mengembangkan diri secara berkelanjutan. Sementara itu, Permendiknas No. 16 Tahun 2007 tentang Kualifikasi dan Kompetensi Guru menjelaskan kompetensi kepribadian untuk guru kelas dan guru mata pelajaran, pada semua jenjang pendidikan dasar dan menengah adalah (1) bertindak sesuai dengan norma agama, hukum, sosial, dan kebudayaan nasional Indonesia; (2) menampilkan diri sebagai pribadi yang jujur, berakhlak mulia, dan teladan bagi peserta didik dan masyarakat; (3) menampilkan diri sebagai pribadi yang mantap, stabil, dewasa, arif, dan berwibawa, mencakup; (4) menunjukkan etos kerja, tanggung jawab yang tinggi, rasa bangga menjadi guru, dan rasa percaya diri; dan (5) menjunjung tinggi kode etik profesi guru. Keterkaitan antara nilai revolusi mental dengan indikator kompetensi kepribadian guru memunculkan sebuah asumsi bahwa ika pada lingkungan pendidikan desa terpencil dilakukan gerakan revolusi mental berbasis kearifan lokal, maka akan meningkatkan kompetensi kepribadian guru SD terpencil khsusnya PNS, yang selama ini sering mangkir dalam menjalankan tugasnya. Dengan demikian, gerakan revolusi mental adalah solusi dan upaya yang tepat dalam meningkatkan kompetensi kepribadian dan kompetensi sosial guru khususnya di SD terpencil.

\section{SIMPULAN DAN SARAN}

\section{Simpulan}

Model revolusi mental pada lingkungan pendidikan desa terpencil adalah pembinaan nilai-nila, integritas, etos klerja, dan gotong royong berbasis kearifan lokal melalui sosialiosasi, pemasangan tagline, dan pelaksanaan upacara untuk memperingati hari besar nasional sebagai uapaya meningkatkan kompetensi sosial dan kompetensi pribadi guru PNS desa terpencil. Model revolusi mental berbasis kearifan lokal desa terpencil dapat meningkatkan pemahaman dan penerapan nilai-nilai revolusi mental oleh guru PNS SD terpencil. Untuk meningkatkan kompetensi guru PNS SD terpencil tersebut, gerakan revolusi mental tepat untuk diterapkan karena nilai-nilai yang diusung dalam gerakan revolusi mental adalah indikator-indikator yang dikembangkan berdasarkan kompetensi sosial dan kompetensi pribadi guru. Gerakan revolusi mental bukan pekerjaan sesaat, maka dalam pelaksanaanya harus konsisten dan terus berkesambungan, dilakukan oleh warga sekolah dan warga masyarakat, oleh karena itu upaya merealisasikannya harus sitematis dan terencana, melibatkan komponen-komponen terkait kepala dinas, kepala UPTD, pengawas sekolah sebagai administrator, motivator, dan fasilitator.

\section{Saran}

Semangat dan upaya meningkatkan kinerja guru PNS SD terpencil khusunya dalam meningkatkan kompetensi pribadi dan sosial melalui gerakan revolusi mental harus didengungkan ke berbagai lapisan masyarakat, lembaga, pemerintah terutama guru-guru sebagai sasaran, melalui aturan atau kebijakan pemerintah setempat. Untuk menjamin komitmen dan kesinambungan gerakan, disarankan untuk memebntuk relawan gerakan revolusi mental, khusunya di SD terpencil, serta membuat kebijakan yang memungkinkan para penanggung jawab mempunyai visi dan misi yang sama dalam membangun kepribadian guru dan siswa di daerah terpencil. Gerakan revolusi mental, harus dapat dirasakan oleh masyarakat sebagai salah satu komponen penerima dampaknya. Oleh karena itu nilai-nilai adat budaya (kearifan lokal) harus menjadi acuan gerakan revolusi mental di berbagai daerah, khusunya daerah terpencil yang syarat dengan nilai-nilai adat dan budayanya.

\section{DAFTAR RUJUKAN}

ACDP Indonesia. 2015. Guru Terpencil Kerap Mangkir. (Online), (https://acdpindonesia. wordspress.com), diakses 26Agustus 2016.

Akmal, Akmal. 2017 . Local Culture And Morality Attachment To Tpack Framework of PreService English Teachers Within The Chalenge Of The 21st Century Skills, UPI: International Journal Of Education, 9 (2). 
Ana, J Egalite. 2015. Representation In The Classroom: The Effect Of Own-Race Teachers On Student Achievement. Journal Economics of Education Review, 45, 44-52.

Anik, Ghufron. 2017. Pengembangan Pembelajaran Berbasis Nilai-silai Budaya Yogyakarta di Sekolah Dasar. UNY : Jurnal Cakrawala Pendidikan, 1. Dari https: //journal.uny.ac.id/ index.php/cp/article/view/12449.

Ary Ginanjar Agustian. 2016. Revolusi mental Berrbasis ESQ. Jakarta: Araga Tilanta

Arianto, Nugroho., \& Agung, Dwi. 2013. Pengaruh Kedisiplinan, Lingkungan Kerja,

dan Budaya Kerja Terhadap Kinerja Tenaga Pengajar. Jurnal Economia, 19 (2).

Arief Budimanta. 2015. Panduan Pencanangan dan Sosialisasi Gerakan Nasional Revolusi mental. Kemenko PMK: Buku Saku Seri 3.

Dihamri. 2016. Kearifan Lokal Suku Serawai di Kabupaten Bengkulu Selatan. tidak diterbitkan. Bengkulu: Lembaga Penelitian UNIHAZ.

Dodo, Sutardi. 2016. Pengembangan Model Belajara BERMUTU yang Adaptif untuk Meningkatkan Kinerja Guru SD Terperncil di Bengkulu. UM: Jurnal Sekolah Dasar, 25 (2).

Ekorusyono, YY. (2013). Mengenal Budaya Enggano, Bengkulu. Yogyakarta: Buku Litera.

Ignas, Kleden. 2014. Revolusi Mental sebagai Teori Pembangunan. Jakarta: Institut Darma Mahardika.

Jansen, Sinamo. 2014. Aplikasi Revolusi Mental: Revolusi Etos Kerja . Jakarta: Institut Darma Mahardika.

Depdiknas. 2006. Tata Kelakuan Pergaulan Keluarga dan Masyarakat Daerah Bengkulu. Bengkulu : Dinas Pendidikan Nasional .
Menpora,. 2017. Paskibraka Adalah Role Model Revolusi Mental. Kantor Beri Politik: RMOL.(Online), (http://www.rmol.co/read/2017/08/23/304222/ Menpora-Imam:-Paskibraka-Adalah-Role), $\quad d i$ akses 23 Agustus 2017.

Murwati, Hesti. 2013. Pengaruh Sertifikasi Profesi Guru Terhadap Motivasi Kerja dan Kinerja Guru Di SMK Negeri Surakarta. Jurnal Pendidikan Bisnis dan Ekonomi (BISE), 1 (1).

Suprastowo, Philip. 2013. Kajian Tentang Tingkat ketidakhadiran guru sekolah dasar dan Dampaknya terhadap Siswa. Jurnal Pendidikan dan Kebudayaan, 19 (1).

Raja, Lailatul Zuraida. 2017. Graphing Calculator Skills Test Item for Circles Topic Using Research Measurement Model Analysis. International Journal of Academic Research in Business and Social Sciences, 2 (1).

Risalah, Risa. 2017. Upaya Meningkatkan Disiplin Belajar Siswa di SD 107. Laporan KKN, tesis tidak diterbitkan. Bengkulu: LPPM UNIHAZ.

Saxe, Leonardo., \& Fine, Michelle. 1989). Social Experiment. California: SAGE Publication, Inc.

Sugiyono. 2011. Metode Penelitian Kuantitatif, Kualitatif, dan $R \& D$. Bandung: ALFABETA.

Wardani, Kristi. 2010. Peran Guru Dalam Pendidikan Karakter Menurut Konsep Pendidikan Ki Hadjar Dewantara. Makalah disajikan pada Proceedings of The 4th International Conference on Teacher Education; Join Conference UPI \& UPSI Bandung, Indonesia, 8-10 November.

Latif, Yudi. 2014. Keharusan Revolisi Mental. Jakarta: Institut Dharma Mahardika. 